\title{
MASS AND DENSITY OF PINE PULPWOOD HARVESTED IN SELECTED STANDS FROM THE FOREST EXPERIMENTAL STATION IN MUROWANA GOŚLINA
}

\author{
Arkadiusz Tomczak ${ }^{1 凶}$, Marcin Jakubowski ${ }^{1}$, Tomasz Jelonek ${ }^{1}$, Radosław Wąsik², \\ Witold Grzywiński ${ }^{1}$
}

\author{
${ }^{1}$ Department of Forest Utilisation, Poznań University of Life Sciences \\ Wojska Polskiego 71 A, 60-625 Poznań, Poland \\ 2Department of Forest and Wood Utilisation, University of Agriculture in Krakow \\ 29 Listopada, 31-425 Krakow, Poland
}

\begin{abstract}
The aim of this analysis was to determine the mass of pine pulpwood, harvested from fresh-cutting trees. Analyses were made in four pine stands (aged 45, 47, 55 and 56). In each plot a total of 30 model trees were selected from among trees to be felled as a part of planned intermediate cutting. The average mass of one log of $2.5 \mathrm{~m}$ length ranged from $26.3 \mathrm{~kg}$ to $44.0 \mathrm{~kg}$, at a mean of $33.9 \mathrm{~kg}$. The total volume of timber harvested was $21.68 \mathrm{~m}^{3}$ with a total mass of $21222.4 \mathrm{~kg}$. When converted to $1 \mathrm{~m}^{3}$ the mass of timber was assessed at $979 \mathrm{~kg}$. The ratio of actual density $\left(979 \mathrm{~kg} / \mathrm{m}^{3}\right)$ to tabular density $\left(740 \mathrm{~kg} / \mathrm{m}^{3}\right)$ was thus $1.3: 1$. As a result the actual mass of timber is approx. $30 \%$ higher than the mass that may be estimated based on the tabular density of wood assessed for the purpose of road transportation. At the stem profile the mass of logs decreases (which is the result of stem diameter decreasing with height), while green density increases. The increase in green density of logs is probably the result of changes in porosity and moisture content of wood, as well as changes in the proportion and properties of bark.
\end{abstract}

Key words: green density, transport, fresh-cutting trees

\section{INTRODUCTION}

In 2012 because of increasing transport problems the Ministers of the Environment and of the Economy announced the regulation concerning the wood density in transport (Rozporządzenie..., 2012). A series of technical roadside inspections showed that the total mass of vehicles together with their cargo substantially exceeded admissible limits. According to a study by Trzciński $(2010,2011)$, the mass of trucks with timber ranged from approx. 40 ton to approx. 60 ton and the mean loading of a single axle vehicle ranged from $70 \mathrm{kN}$ to $120 \mathrm{kN}$. The discrepancies resulted mainly from the difference in mass typical of individual wood species. Within the same species differences were also observed for individual sortments. Trzciński (2011) also stated that transported loads of large-sized pine timber of min. $21 \mathrm{~m}^{3}$ exceed the admissible mass of the vehicle and cargo set. This would result in a considerable reduction of loads in relation to transportation vehicles' capacity.

Based on the above-mentioned regulation the maximum volume $\left[\mathrm{m}^{3}\right]$ and mass $[\mathrm{kg}]$ of timber per single trailer vehicle was specified. In practice this

凶arkadiusz.tomczak@up.poznan.pl 
means that the actual wood mass is the mass of timber, i.e. xylem, contained water, phloem and bark. Wanin (1953) reported that $1 \mathrm{~m}^{3}$ of freshly harvested pine timber weighs $863 \mathrm{~kg}$. Krzysik (1978 reported from Trendelenburg 1939) that green density of pine timber is $750 \mathrm{~kg} / \mathrm{m}^{3}$ (diameter more than $40 \mathrm{~cm}$ ), $800 \mathrm{~kg} / \mathrm{m}^{3}$ (diameter from $20 \mathrm{~cm}$ to $40 \mathrm{~cm}$ ) and $880 \mathrm{~kg} / \mathrm{m}^{3}$ (diameter below $20 \mathrm{~cm}$ ). Generally, wood density is highly variable, dependent mainly on porosity (wood species) and wood moisture content (Krzysik, 1978). When analysing variability in wood density within a species, we may also observe the effect of the social class of a tree's position in the stand, habitat or geographical location (Paschalis, 1980; Wiemann and Wiliamson, 2001). Density along with other properties and characteristics of wood will, moreover, depend on the position of wood within the stem, the pattern of annual rings and the proportion of late wood and earlywood (Tomczak, 2013; Tomczak and Jelonek, 2014; Tomczak et al., 2010; Witkowska and Lachowicz, 2013).

The bark is also an important component of the mass of pulpwood. The bark of Scots pine was investigated by Bauza (1971), who stated that the basic density of air-dry dead bark is $385 \mathrm{~kg} / \mathrm{m}^{3}$. Dietz (1975) in turn reported that the basic density of pine bark is $300 \mathrm{~kg} / \mathrm{m}^{3}$. According to Wróbel (1975), the density of air-dry bark depends on its type and ranges from between $370 \mathrm{~kg} / \mathrm{m}^{3}$ and $390 \mathrm{~kg} / \mathrm{m}^{3}$ (dead bark, i.e. cracked, brown bark on the stems of older trees) to between $510 \mathrm{~kg} / \mathrm{m}^{3}$ and 550 $\mathrm{kg} / \mathrm{m}^{3}$ (smooth, reddish bark on the stems of younger trees or in higher parts of older trees). The density of smooth bark is close to that of wood. The density of air-dry pine wood ranges from $450 \mathrm{~kg} / \mathrm{m}^{3}$ to $650 \mathrm{~kg} / \mathrm{m}^{3}$ (Głowacki and Paschalis, 1991; Kobyliński, 1967). The share and density of bark are of importance when estimating the above-ground biomass of forests (Jabłoński and Budniak, 2014), particularly in the case of Scots pine, which predominates in Poland (Orzeł et al., 2006). Ochał et al. (2013) calculated that the share of bark in aboveground tree biomass is approx. 7\%. In stem biomass the share of bark will be higher. According to Grochowski $(1953,1956)$, in age class V (80-100 years) the share of bark in the stem volume of a pine stand (90 year-old; site index II/III) may be estimated at 14\%. A similar result was obtained by Rymer-Dudzińska (1964), who assessed that in even-aged pine stands the mean percentage of bark volume ranges from $13 \%$ to
16\%. Meixner (1970) also showed that the proportion of bark in - stem volume in pines aged 35 years is approx. $17 \%$, while in an 88 -year old stand it is approx. $13.5 \%$. The issue concerning the proportion of bark in the volume of single trees or whole pine stands is frequently discussed in literature, mainly by Rymer-Dudzińska $(1973,1976,1981,1997)$. Data concerning the proportion of bark may also be found in volume and trunk slenderness tables of Scots pine logs, prepared by Radwański (1955).

As well as bark, water is an equally significant component of timber mass. Water in wood is divided into three types: constitutive (in plasma and sap), bound (filling spaces in cell walls) and free (in pores of wood). The water content of wood is determined by swelling and shrinkage. As a hygroscopic material wood is capable of vapour exchange with the environment. This phenomenon occurs solely in the hygroscopic range, the upper limit of which is defined by the maximum cell wall swelling point (assumed to be 30\%). Water content in a tree stem depends on the species, the age and the season of the year, for example. A greater water content is found in softwoods, i.e. wood of coniferous species, and hardwoods, i.e. deciduous species, with softer wood. Sapwood and heartwood differ greatly in terms of their moisture content. In pine the moisture content of sapwood is almost three times that of heartwood. At the stem profile there are two moisture content maxima, one located at the base of stem and the other in the apical part of the stem, containing sapwood. Winter is the season when pine has the greatest moisture (Krzysik, 1978; Wanin, 1955).

Mass and density of timber, i.e. mass per $1 \mathrm{~m}^{3}$, may thus vary correspondingly to factors directly affecting these values. The actual mass of timber is not currently determined when timber is loaded on to road vehicles. An estimate is used, a product of volume converted into mass, with mass being a constant value, in accordance with the table attached to the ordinance of the Minister of the Environment and the Minister of Economy on the determination of wood density (Rozporządzenie..., 2012). In the case of pine we assume a density of $740 \mathrm{~kg} / \mathrm{m}^{3}$, i.e. a mass of $740 \mathrm{~kg}$ per $1 \mathrm{~m}^{3}$ of timber. This paper presents the results of pilot studies, the aim of which was to determine the mass and green density of pine pulpwood (wood with bark), harvested from fresh-cutting trees. 
Table 1. Selected data on experimental plots

Tabela 1. Wybrane cechy taksacyjne powierzchni doświadczalnych

\begin{tabular}{|c|c|c|c|c|c|c|c|}
\hline $\begin{array}{c}\text { Forest } \\
\text { district } \\
\text { Leśnictwo }\end{array}$ & $\begin{array}{l}\text { Symbol of plot } \\
\text { Symbol } \\
\text { powierzchni }\end{array}$ & $\begin{array}{c}\text { Type } \\
\text { of forest site } \\
\text { Siedliskowy } \\
\text { typ lasu }\end{array}$ & $\begin{array}{l}\text { Age } \\
\text { years } \\
\text { Wiek } \\
\text { lata }\end{array}$ & $\begin{array}{l}\text { Quality } \\
\text { index } \\
\text { Bonitacja }\end{array}$ & $\begin{array}{l}\text { Mass of timber } \\
\text { harvested with bark } \\
\text { Masa surowca } \\
\text { pozyskanego } \\
\text { z korą } \\
\text { kg }\end{array}$ & $\begin{array}{c}\text { Volume of timber } \\
\text { inside bark } \\
\text { Miąższość } \\
\text { w korze } \\
\mathrm{m}^{3}\end{array}$ & $\begin{array}{c}\text { Volume of timber } \\
\text { outside bark } \\
\text { Miąższość } \\
\text { bez kory } \\
\mathrm{m}^{3}\end{array}$ \\
\hline \multirow[t]{2}{*}{ Potasze } & $\mathrm{P}_{1}$ & LMśw & 47 & Ia & 3502.7 & 3.54 & 3.22 \\
\hline & $\mathrm{P}_{2}$ & BMśw & 45 & & 4013.5 & 4.46 & 4.13 \\
\hline \multirow[t]{2}{*}{ Stęszewko } & $\mathrm{S}_{1}$ & LMśw & 55 & & 5792.6 & 6.80 & 6.30 \\
\hline & $\mathrm{S}_{2}$ & BMśw & 56 & & 7913.6 & 8.55 & 8.03 \\
\hline
\end{tabular}

LMśw - fresh mixed forest, BMśw - fresh mixed coniferous forest.

LMśw - las mieszany świeży, BMśw - bór mieszany świeży.

\section{MATERIAL AND METHODS}

Analyses were conducted at the Forest Experimental Station in Murowana Goślina (Poznań University of Life Sciences). Four pine stands were selected from a group of those, in which intermediate cutting was planned. Stands selection based on the following criteria: age, habitat and site index (Table 1).

In each plot the diameter at breast height of 100 trees earmarked to be felled was measured twice, at the smallest and greatest diameters, with the mean result recorded in the respective diameter sub-class. A 2-cm diameter gradation was assumed starting from $7 \mathrm{~cm}$. In proportion to the number of trees in the sub-class heights were measured using the Sunnto hypsometer (from a distance of $20 \mathrm{~m}$ ). Based on collected data the reference sample trees were selected using the Draudt's method, assuming that each plot would be represented by 30 trees (the coefficient of $0.3)$. Multiplication of the number of trees in a given diameter sub-class by the coefficient showed the number of mean sample trees it would be represented by. The application of this method facilitates the selection of representatives samples from the entire population of trees to be harvested.

After felling the selected trees, their length was measured with a tape accurate to $0.1 \mathrm{~m}$ in order to amend the measurements taken from standing trees. After delimbing, logs of $2.5 \mathrm{~m}$ length were cut. Minimum diameter at the small end - was $7 \mathrm{~cm}$ outside bark.
The number of logs produced from one stem ranged from 2 to 8 . The minimum and maximum diameters were then measured for each of the stem cross-butt ends, both inside and outside bark. Using the lower and upper diameters of the log their volumes outside bark (wk) and inside bark (bk) were calculated using Smalian's formula. After diameter measurements were taken, each log was weighed. Mass was determined accurate to $0.1 \mathrm{~kg}$. Analyses were conducted in February 2014. In that month the recorded temperature ranged from -3 to $11^{\circ} \mathrm{C}$ and relative humidity ranged from $39 \%$ to $100 \%$.

The collected data were analysed and descriptive statistics were prepared. The data were not normally distributed. Differences were tested using the post-hoc Shaffé's test. All calculations were performed using the Statistica application (StatSoft Inc.).

\section{RESULTS}

The average diameter at breast height for the mean sample trees in individual plots ranged from $14 \mathrm{~cm}$ to $19.9 \mathrm{~cm}$, while their height ranged from $16.6 \mathrm{~m}$ to $20.9 \mathrm{~m}$. Generally trees grown in the fresh mixed forest (LMśw) were shorter and had smaller diameters at breast height in comparison to those from the fresh mixed coniferous forest (BMśw). Statistically significant differences observed between diameters at breast height in older trees and younger trees. Both analysed traits also differed significantly between 
Tomczak, E., Jakubowski, M., Jelonek, T., Wąsik, R., Grzywiński, W. (2016). Mass and density of pine pulpwood harvested in selected stands from the Forest Experimental Station in Murowana Goślina. Acta Sci. Pol. Silv. Colendar. Ratio Ind. Lignar., 15(2), 105-112. DOI: 10.17306/J.AFW.2016.2.13

Table 2. A comparison of average diameters at breast height and height of the mean sample trees

Tabela 2. Porównanie pierśnic i wysokości drzew modelowych

\begin{tabular}{|c|c|c|c|c|c|c|c|}
\hline & & \multicolumn{3}{|c|}{ Diameter at breast height - Pierśnica } & \multicolumn{3}{|c|}{ Height of tree - Wysokość } \\
\hline & $n$ & $\begin{array}{l}\text { mean, } \mathrm{cm} \\
\text { średnia, } \mathrm{cm}\end{array}$ & SD & $\mathrm{VC}, \%$ & $\begin{array}{c}\text { mean, m } \\
\text { średnia, m }\end{array}$ & $\mathrm{SD}$ & $\mathrm{VC}, \%$ \\
\hline $\mathrm{P}_{1}$ & 30 & $14.0^{\mathrm{S} 1 \mathrm{~S} 2}$ & 1.7 & 12.4 & $16.6^{\mathrm{P} 2 \mathrm{~S} 1 \mathrm{~S} 2}$ & 0.9 & 5.5 \\
\hline $\mathrm{P}_{2}$ & 30 & $14.9^{\mathrm{S} 1 \mathrm{~S} 2}$ & 2.4 & 16.0 & $17.6^{\mathrm{P} 1 \mathrm{~S} 1 \mathrm{~S} 2}$ & 1.6 & 9.2 \\
\hline $\mathrm{S}_{1}$ & 30 & $17.9^{\mathrm{P} 1 \mathrm{P} 2 \mathrm{~S} 2}$ & 3.0 & 16.8 & $20.2^{\mathrm{P} 1 \mathrm{P} 2}$ & 2.0 & 9.9 \\
\hline $\mathrm{S}_{2}$ & 30 & $19.9^{\mathrm{P} 1 \mathrm{P} 2 \mathrm{~S} 1}$ & 3.4 & 17.2 & $20.9^{\mathrm{P} 1 \mathrm{P} 2}$ & 1.8 & 8.7 \\
\hline
\end{tabular}

$n$ - number of trees, $\mathrm{SD}$ - standard deviation, $\mathrm{VC}$ - variability coefficient. ${ }^{\text {P1 P2 S1 S2 }}$ marked differences are significant with $p<0.05$. $n$ - liczba drzew, SD - odchylenie standardowe, VC - współczynnik zmienności. P1 P2 S1 S2 zaznaczone różnice są istotne z $p<0,05$.

younger ( 45 to 47 year-old) and older ( 55 to 56 year-old) stands (Table 2). Between the diameter at breast height and the mass of timber a very strong relationship was observed (Spearman's rank correlation of 0.95 at $p<0.01)$. A similarly strong dependence was also found between mass of timber and tree height $(0.91$ at $p<0.01)$.

In plot $\mathrm{P}_{1}$ harvested $3.54 \mathrm{~m}^{3}$ timber (with bark), with the total mass of $3503 \mathrm{~kg}$. In plot $\mathrm{P}_{2}$ it was $4.46 \mathrm{~m}^{3}$, with a total mass of $4014 \mathrm{~kg}$. In the older stands the total volume of timber collected from the 30 mean sample trees was $6.80 \mathrm{~m}^{3}$ in plot $\mathrm{S}_{1}$ and $8.55 \mathrm{~m}^{3}$ in plot $\mathrm{S}_{2}$. The mass of timber in plots $\mathrm{S}_{1}$ and $\mathrm{S}_{2}$ was $5793 \mathrm{~kg}$ and $7914 \mathrm{~kg}$, respectively (Table 1). The mass of timber harvested from individual stands, converted per $1 \mathrm{~m}^{3}$, was $989.5 \mathrm{~kg}\left(\mathrm{P}_{1}\right), 900 \mathrm{~kg}\left(\mathrm{P}_{2}\right)$, $851.9 \mathrm{~kg}\left(\mathrm{~S}_{1}\right)$ and $925.6 \mathrm{~kg}\left(\mathrm{~S}_{2}\right)$. In plot $\mathrm{P}_{1} 0.32 \mathrm{~m}^{3}$ bark was collected and in plot $\mathrm{P}_{2}$ it was $0.33 \mathrm{~m}^{3}$, while in plots $S_{1}$ and $S_{2}$ it was 0.50 and $0.52 \mathrm{~m}^{3}$ respectively. The proportion of bark in the volume of timber harvested may thus be estimated at $9.9\left(\mathrm{P}_{1}\right), 8.0\left(\mathrm{P}_{2}\right)$, $7.9\left(\mathrm{~S}_{1}\right)$ and $6.5 \%\left(\mathrm{~S}_{2}\right)$.

The mean mass of a $2.5 \mathrm{~m} \mathrm{log}$ in plot $\mathrm{P}_{1}$ (47-year old stand; LMśw), at the volume of $0.027 \mathrm{~m}^{3}$ (wood + bark) was $26.3 \mathrm{~kg}$. In plot $\mathrm{P}_{2}$ (45-year old stand; BMśw) the mean volume of $0.031 \mathrm{~m}^{3}$ and mean mass of $27.7 \mathrm{~kg}$ were harvested. In plots $\mathrm{S}_{1}$ (55-year old stand; LMśw) and $\mathrm{S}_{2}$ (56-year old stand; BMśw), the mean mass of $\log$ was $34.5 \mathrm{~kg}$ (mean volume 0.041 $\mathrm{m}^{3}$ ) and $44 \mathrm{~kg}\left(\right.$ mean volume $\left.0.048 \mathrm{~m}^{3}\right)$. Statistically significant differences were found between younger and older stands, and between $\mathrm{S}_{1}$ and $\mathrm{S}_{2}$. When comparing measures of location it was found that medians are lower than arithmetic means. Thus, data with extremely high values were found. The maximum mass of a $\log$ in plot $\mathrm{P}_{1}$ was $57.6 \mathrm{~kg}$, in plot $\mathrm{P}_{2}$ it was $81.3 \mathrm{~kg}$, in plot $\mathrm{S}_{1} 85.1 \mathrm{~kg}$ and in plot $\mathrm{S}_{2}$ it was $163.5 \mathrm{~kg}$. The minimum mass was $12.6 \mathrm{~kg}$, $12.7 \mathrm{~kg}, 12.4 \mathrm{~kg}$ and $3.5 \mathrm{~kg}$. The average density of a log ranged from $891 \mathrm{~kg} / \mathrm{m}^{3}$ to $1045 \mathrm{~kg} / \mathrm{m}^{3}$. From the stem of one mean sample tree (depending on the plot) a mean of between $0.12 \mathrm{~m}^{3}$ and $0.29 \mathrm{~m}^{3}$ timber was collected. Its total mass ranged from approx. $117 \mathrm{~kg}$ to approx. $264 \mathrm{~kg}$ (Table 3).

Stem diameter decreases along its longitudinal axis; consequently the volume of logs and its mass decrease. Very strong relationships are observed between mass, diameter and volume of timber. At the significance level $p<0.01$ the rank correlation assumes the value of 0.97 for the relationship between the mass and volume of a log under bark and outside bark. A similarly powerful relationship was found between the mass of a log and its diameter (0.96). In contrast to mass, the density of a $\log$, i.e. the ratio of its mass to volume, increases with a decrease in diameter and volume. The value of the correlation coefficient characterising the relationship between timber density and its volume was established at -0.7 , with a similarly strong relationship shown between timber density and diameter. 
Tomczak, E., Jakubowski, M., Jelonek, T., Wąsik, R., Grzywiński, W. (2016). Mass and density of pine pulpwood harvested in selected stands from the Forest Experimental Station in Murowana Goślina. Acta Sci. Pol. Silv. Colendar. Ratio Ind. Lignar., 15(2), 105-112. DOI: 10.17306/J.AFW.2016.2.13

Table 3. Mass, volume and green density of pine pulpwood

Tabela 3. Masa, miąższość i gęstość średniowymiarowego surowca sosnowego w stanie świeżym

\begin{tabular}{|c|c|c|c|c|c|c|c|c|c|}
\hline & $\begin{array}{c}\text { Plot } \\
\text { Powierzchnia }\end{array}$ & $\begin{array}{l}\text { Mean } \\
\text { Średnia }\end{array}$ & SD & $\mathrm{VC}, \%$ & $\min$ & $\max$ & Q25 & $\begin{array}{l}\text { Median } \\
\text { Mediana }\end{array}$ & Q75 \\
\hline \multirow{4}{*}{$\begin{array}{l}\text { Mass of log, } \mathrm{kg} \\
\text { Masa wałka, kg }\end{array}$} & $\mathrm{P}_{1}$ & $26.3^{\mathrm{S} 1 \mathrm{~S} 2}$ & 9.8 & 37.4 & 12.6 & 57.6 & 19.0 & 23.7 & 31.6 \\
\hline & $\mathrm{P}_{2}$ & $27.7^{\mathrm{S} 1 \mathrm{~S} 2}$ & 11.6 & 41.9 & 12.7 & 81.3 & 19.4 & 25.0 & 32.3 \\
\hline & $\mathrm{S}_{1}$ & $34.5^{\text {P1 P2 S2 }}$ & 15.2 & 44.2 & 12.4 & 85.1 & 22.4 & 30.4 & 42.5 \\
\hline & $\mathrm{S}_{2}$ & $44.0^{\mathrm{P} 1 \mathrm{P} 2 \mathrm{~S} 1}$ & 23.0 & 52.3 & 3.5 & 163.5 & 28.3 & 38.4 & 54.0 \\
\hline \multirow{4}{*}{$\begin{array}{l}\text { Volume of } \log , \mathrm{m}^{3} \\
\text { Miąższość wałka, } \mathrm{m}^{3}\end{array}$} & $\mathrm{P}_{1}$ & $0.027^{\mathrm{P} 2 \mathrm{~S} 1 \mathrm{~s} 2}$ & 0.013 & 49.5 & 0.010 & 0.075 & 0.017 & 0.023 & 0.034 \\
\hline & $\mathrm{P}_{2}$ & $0.031^{\mathrm{P} 1 \mathrm{~S} 1 \mathrm{~S} 2}$ & 0.017 & 55.0 & 0.012 & 0.108 & 0.019 & 0.025 & 0.039 \\
\hline & $\mathrm{S}_{1}$ & $0.041^{\mathrm{P} 1 \mathrm{P} 2 \mathrm{~S} 2}$ & 0.021 & 52.7 & 0.013 & 0.111 & 0.025 & 0.035 & 0.051 \\
\hline & $\mathrm{S}_{2}$ & $0.048^{\mathrm{P} 1 \mathrm{P} 2 \mathrm{~S} 1}$ & 0.028 & 59.9 & 0.012 & 0.192 & 0.028 & 0.040 & 0.061 \\
\hline \multirow{4}{*}{$\begin{array}{l}\text { Density of } \log , \mathrm{kg} / \mathrm{m}^{3} \\
\text { Gęstość wałka, } \mathrm{kg} / \mathrm{m}^{3}\end{array}$} & $\mathrm{P}_{1}$ & $1045^{\mathrm{s} 1 \mathrm{~S} 2}$ & 139 & 13 & 695 & 1323 & 922 & 1083 & 1138 \\
\hline & $\mathrm{P}_{2}$ & $956^{\mathrm{P1} \text { S2 }}$ & 140 & 15 & 608 & 1297 & 855 & 977 & 1057 \\
\hline & $\mathrm{S}_{1}$ & $891^{\text {P1 P2 S2 }}$ & 118 & 13 & 649 & 1236 & 803 & 892 & 968 \\
\hline & $\mathrm{S}_{2}$ & $978^{\text {P1 S1 }}$ & 158 & 16 & 126 & 1384 & 885 & 977 & 1060 \\
\hline \multirow{4}{*}{$\begin{array}{l}\text { Mass of pulpwood } \\
\text { harvested from one } \\
\text { stem, kg } \\
\text { Masa surowca pozyska- } \\
\text { nego z jednego pnia, kg }\end{array}$} & $\mathrm{P}_{1}$ & $116.8^{\mathrm{s} 1 \mathrm{~S} 2}$ & 37.8 & 32.4 & 52.8 & 205.1 & 88.2 & 105.3 & 140.3 \\
\hline & $\mathrm{P}_{2}$ & $133.8^{\mathrm{s} 1 \mathrm{~s} 2}$ & 59.2 & 44.2 & 30.4 & 320.8 & 98.4 & 128.4 & 156.2 \\
\hline & $\mathrm{S}_{1}$ & $193.1^{\text {P1 P2 S2 }}$ & 76.3 & 39.5 & 80.8 & 364.0 & 130.1 & 175.6 & 250.3 \\
\hline & $\mathrm{S}_{2}$ & $263.8^{\text {P1 P2 S1 }}$ & 123.5 & 46.8 & 124.6 & 739.5 & 194.2 & 227.2 & 292.6 \\
\hline \multirow{4}{*}{$\begin{array}{l}\text { Volume of pulpwood } \\
\text { collected from one } \\
\text { stem, } \mathrm{m}^{3} \\
\text { Miąższość surowca } \\
\text { pozyskanego z jednego } \\
\text { pnia, m }\end{array}$} & $\mathrm{P}_{1}$ & $0.118^{\mathrm{P} 2 \mathrm{~S} 1 \mathrm{~S} 2}$ & 0.039 & 33.2 & 0.057 & 0.221 & 0.088 & 0.109 & 0.144 \\
\hline & $\mathrm{P}_{2}$ & $0.149^{\mathrm{P} 1 \mathrm{~S} 1 \mathrm{~S} 2}$ & 0.066 & 44.1 & 0.041 & 0.365 & 0.100 & 0.143 & 0.171 \\
\hline & $\mathrm{S}_{1}$ & $0.227^{\mathrm{P} 1 \mathrm{P} 2 \mathrm{~S} 2}$ & 0.089 & 39.1 & 0.095 & 0.422 & 0.165 & 0.208 & 0.277 \\
\hline & $\mathrm{S}_{2}$ & $0.285^{\mathrm{P} 1 \mathrm{P} 2 \mathrm{~S} 1}$ & 0.128 & 44.8 & 0.149 & 0.768 & 0.210 & 0.243 & 0.325 \\
\hline
\end{tabular}

Symbols as in the Table 2. ${ }^{\text {P1 P2 S1 S2 }}$ marked effects are significant with $p<0.05$.

Oznaczenia jak w tabeli 2. ${ }^{\text {P1 P2 S1 S2 }}$ zaznaczone efekty są istotne $\mathrm{z} p<0,05$.

\section{DISCUSSION}

The aim of this analysis was to determine the mass of pine pulpwood, harvested from fresh-cutting trees. Analyses were conducted in February, a period when wood moisture content is at its highest point. In comparison in February the moisture content of sapwood is higher than in July. Differences in the moisture content of heartwood are markedly smaller (Bielczyk and Eminowicz; 1954). Generally, due to the conducting function it serves, sapwood is characterised by a markedly greater moisture content than heartwood. The effect of heartwood on recorded results was probably slight, since the share of heartwood in the stems of pines in age class III (40-60 years) is estimated at around a dozen percent (Jakubowski, 2004; Jelonek et al., 2005).

Mass, volume and density were determined with bark, i.e. in the condition in which timber is prepared for quality inspection and transport. Bark proportion in the logs volume will affect the total mass of logs and its density. In comparison to wood mass, the mass 
of $1 \mathrm{~m}^{3}$ of timber will be greater by tens kilograms because of the bark. The opposite trend is found for density, particularly where there is a considerable proportion of dead bark in the timber volume. Krzysik (1978) from Trendelenburg (1939) reported timber density depending on its diameter. This ranges between 750 $\mathrm{kg} / \mathrm{m}^{3}$ and $880 \mathrm{~kg} / \mathrm{m}^{3}$, while a lower density is found in timber of greater diameter, and vice versa. Based on the recorded results an analogous dependence was observed. The mass and volume of logs decreased as the distance from the base of stem grew, which is the clear effect of the stem diameter decreasing with tree height, while timber density was increasing. In stands of younger age classes medium-sized timber was collected from whole stems, while in older stands it was obtained mainly from the apical parts. The variation in mass along the stem may be influenced by wood density, which decreases from the base to the top of the stem (Tomczak, 2013; Tomczak et al., 2013; Witkowska and Lachowicz, 2013). Wood of lesser density is lighter and more porous, which means that its water capacity is greater. The increase in timber density from the base to the top of the stem probably results from the disproportionate increment in the volume of water (moisture content) in relation to the volume of wood. Additionally, the analysed variation in timber density needs to be associated with changes in the proportion of bark. In the butt end the bark is thicker, its proportion is higher and, as Wróbel (1975) demonstrated, it is characterised by a lower density than bark from the apical part of the stem. In Scots pine dead bark in the butt end of the stem is thick and markedly cracked, while in the apical part it is thin and smooth.

This paper presents results from four stands selected for analyses from the Forest Experimental Station in Murowana Goślina. They are local in character and at this stage of research they may be characteristic of pine timber only within such an approach. Recorded results indicate significant differences between the value of density assumed for pine wood in the ordinance of the Minister of the Environment and the Minister of Economy, and the value obtained in these analyses. Resulting discrepancies show the need for further studies in this respect. Variation in the mass and density of timber results from the variability in traits modifying it directly and indirectly. Wood density, the proportion of bark and wood moisture content may directly influence the mass of timber, while indirectly it may depend on the season of the year or the type of forest habitat, for example.

\section{CONCLUSIONS}

1. The average mass of one $\log$ (wood + bark) of $2.5 \mathrm{~m}$ in length, collected from the stand of age class III (40-60 years) ranged from $26.3 \mathrm{~kg}$ to $44.0 \mathrm{~kg}$ with a mean of $33.9 \mathrm{~kg}$; volume ranged from $0.027 \mathrm{~m}^{3}$ to $0.048 \mathrm{~m}^{3}$ (mean $0,037 \mathrm{~m}^{3}$ ); while density ranged from $891 \mathrm{~kg} / \mathrm{m}^{3}$ to $1045 \mathrm{~kg} / \mathrm{m}^{3}$ (mean $968 \mathrm{~kg} / \mathrm{m}^{3}$ ).

2. Per $1 \mathrm{~m}^{3}$ the mass of timber was $979 \mathrm{~kg}$ (harvested from fresh-cutting trees). The mass of timber was thus greater than the mass by approx. 30\%, which may be estimated based on tabular wood density prepared for the needs of road transportation $(740 \mathrm{~kg})$.

3. At the stem profile the mass of logs decreases (which is the result of stem diameter decreasing with height), while green density increases. The increase in green density of logs is probably the result of changes in porosity and moisture content of wood, as well as changes in the proportion and properties of bark.

\section{REFERENCES}

Bauza, J. (1971). Badania wybranych właściwości fizycznych i mechanicznych korowiny sosny pospolitej (Pinus sylvestris L.) [The study of selected physical and mechanical properties of Scots pine bark (Pinus sylvestris L.)]. Unpublished doctoral dissertation, Instytut Technologii Drewna [in Polish].

Bielczyk, S., Eminowicz, A. (1954). Wilgotność drewna drzew żywych [Moisture wood for the trees alive]. Rocz. Nauk Leśn., 7 [in Polish].

Dietz, P. (1975). Dichte und Rindengehalt von Industrieholz. Holz als Roh- und Werkstoff., 33, 135-141 [in German].

Głowacki, S., Paschalis, P. (1991). Change in technical properties of pine wood derived resin tapped stands. Folia For. Pol., Ser. A, 33, 45-55.

Grochowski, J. (1953). Z badań nad udziałem kory w miąższości sosny [With research proportion of bark in Scots pine volume]. Sylwan, 97(6), 416-430 [in Polish].

Grochowski, J. (1956). Udział kory w miąższości strzał sosnowych [Bark proportion in volume on Scots pine trunks]. Sylwan, 100(9), 1-24 [in Polish].

Jabłoński, M., Budniak, P. (2014). Szacowanie nadziemnej biomasy drzewnej lasów w Polsce na potrzeby 
Tomczak, E., Jakubowski, M., Jelonek, T., Wąsik, R., Grzywiński, W. (2016). Mass and density of pine pulpwood harvested in selected stands from the Forest Experimental Station in Murowana Goślina. Acta Sci. Pol. Silv. Colendar. Ratio Ind. Lignar., 15(2), 105-112. DOI: 10.17306/J.AFW.2016.2.13

sprawozdawczości EKG/FAO i UNFCCC [Estimating above-ground woody biomass of forests in Poland for UNECE/FAO and UNFCCC reporting]. Leśn. Pr. Bad., 75(3), 277-289. DOI: 10.2478/frp-2014-0027

Jakubowski, M. (2004). Udział bielu, twardzieli, drewna młodocianego i dojrzałego w strzałach sosen zwyczajnych (Pinus sylvestris L.) wyrosłych w różnych warunkach siedliskowych [The share of sapwood, heartwood, juvenile wood and mature wood in pine stems (Pinus sylvestris L.) in relation to site conditions]. Sylwan, 8, 16-24 [in Polish].

Jelonek, T., Pazdrowski, W., Tomczak, A. (2005). Share of sapwood and heartwood in stems of Scots pine wood (Pinus sylvestris L.) growing on forest soils and former farmlands as a basis for the evaluation of timber raw material. Ann. Warsaw Agric. Univ. - SGGW, For. Wood Technol., 56, 296-300.

Kobyliński, F. (1967). Badania podstawowych technicznych właściwości drewna sosnowych drzewostanów nasiennych [Investigation of basic technical properties of wood of pine seed tree]. Sylwan, 11, 53-61 [in Polish].

Krzysik, F. (1978). Nauka o drewnie [Wood science]. Warszawa: PWN [in Polish].

Meixner, J. (1970). Udział kory w miąższości strzał sosny [Bark proportion in volume on Scots pine trunks]. Pr. Kom. Nauk Roln. Leśn., 30, 173-184 [in Polish].

Ochał, W., Grabczyński, S., Orzeł, S., Wertz, B., Socha, J. (2013). Alokacja nadziemnej biomasy u sosen zajmujących różne pozycje biosocjalne w drzewostanie [Above-ground biomass allocation in Scots pines of different biosocial positions in the stand]. Sylwan, 157(10), 737-746 [in Polish].

Orzeł, S., Forgiel, M., Ochał, W., Socha, J. (2006). Nadziemna biomasa i roczna produkcja drzewostanów sosnowych Puszczy Niepołomickiej [Above-ground biomass and annual production in stands of the Niepołomicka Forest]. Sylwan, 9, 16-32 [in Polish].

Paschalis, P. (1980). Zmienność jakości technicznej drewna sosny pospolitej we wschodniej części Polski [The variability of the technical quality of Scots pine wood in the eastern part of the Polish]. Sylwan, 1, 29-43 [in Polish].

Radwański, B. (1955). Tablice miąższości i zbieżystości dłużyc, kłód i wyrzynków strzał sosnowych [Volume and trunk slenderness tables of Scots pine logs]. Warszawa: PWRiL [in Polish].

Rozporządzenie Ministra Środowiska oraz Ministra Gospodarki z dnia 17 maja 2012 r. w sprawie określenia gęstości drewna. [Regulation of Minister of Environment and Minister of Economy] (2012). Dz. U. 2012, poz. 536 [in Polish].
Rymer-Dudzińska, T. (1964). Badania nad udziałem kory w miąższości strzał w drzewostanie sosnowym Puszczy Białej [Investigations in to share of bark in stem volume of pine stands in White Forest (Puszcza Biała)]. Sylwan, 1, 33-41 [in Polish].

Rymer-Dudzińska, T. (1973). Dokładność określania procentu miąższości kory w drzewostanach sosnowych na podstawie tabel Władysława Płońskiego, Bolesława Radwańskiego, Tadeusza Tramplera [The precision of the determination of the bark volume proportion in pine stands on the base of volume tables by W. Płoński, B. Radwański and T. Trampler]. Sylwan, 2, 21-28 [in Polish].

Rymer-Dudzińska, T. (1976). Udział kory w miąższości drzewostanów sosnowych [Bark proportion in the volume of pine stands]. Fol. For. Pol., Ser. A, 22, 223-236 [in Polish].

Rymer-Dudzińska, T. (1981). Udział kory w miąższości świerka w drzewostanach świerkowo-sosnowych i sosnowo-świerkowych [Proportion of bark in the volume of spruce in spruce-pine and pine-spruce stands]. Sylwan, 7, 8, 9, 87-92 [in Polish].

Rymer-Dudzińska, T. (1997). Wzory empiryczne do określania procentu miąższości kory sosny [Empirical formulas for determining proportion of bark in Scot spine]. Sylwan, 6, 17-20 [in Polish].

Tomczak, A. (2013). Selected technical parameters of juvenile wood in Scots pine (Pinus sylvestris L.) - variation between social classes of tree position in the dominant stand. Acta Sci. Pol. Silv. Colendar. Ratio Ind. Lign., 12(4), 43-55.

Tomczak, A, Jelonek, T. (2014). Gęstość drewna z bielastej części przekroju poprzecznego pnia sosny zwyczajnej (Pinus sylvestris L.) pochodzącej z wybranych drzewostanów północno-zachodniej Polski [Green density of Scots pine (Pinus sylvestris L.) sapwood coming from selected stands north-western Poland]. For. Lett., 107, 5-9 [in Polish].

Tomczak, A., Jelonek, T., Pazdrowski, W. (2013). Basic density of Scots pine wood - relationships between values calculated at different heights of the trunk. Ann. Warsaw Agric. Univ. - SGGW, For. Wood Technol., 84, 241-246.

Tomczak, A., Jelonek, T., Zoń, L. (2010). Porównanie wybranych właściwości fizycznych drewna młodocianego i dojrzałego sosny zwyczajnej (Pinus sylvestris L.) $\mathrm{z}$ drzewostanów rębnych [Technical parameters of juvenile and mature wood in Scots pine (Pinus sylvestris L.)]. Sylwan, 154(12), 809-817 [in Polish]. 
Trzciński, G. (2010). Obciążenie dróg leśnych wynikające $\mathrm{z}$ transportu surowca drzewnego [Loading of forest roads resulting from timber transportation]. Techn. Roln. Ogrod. Leśn., 6. Retrieved July 302015 from, http://www.pimr.poznan.pl/trol6_2010/GTRZ6_2010. pdf [in Polish].

Trzciński, G. (2011). Wywóz drewna wielkowymiarowego a obciążenie dróg leśnych [Impact of the timber haulage on loading of the forest roads]. Probl. Inż. Roln., 1, 185-193 [in Polish].

Wanin, S. (1953). Nauka o drewnie [Wood science]. Warszawa: PWRiL [in Polish].

Wiemann, M. C., Wiliamson, G. B. (2001). Geographic variation in wood specific gravity. Effect of latitude, temperature and precipitation. Wood Fiber Sci., 34(1), 96-107.

Witkowska, J., Lachowicz, H. (2013). Zmienność gęstości umownej drewna sosny zwyczajnej (Pinus sylvestris L.) w zależności od wybranych czynników [Variability of conventional wood density of Scots pine (Pinus sylvestris L.) depending on the selected factors]. Sylwan, 157(5), 336-347 [in Polish].

Wróbel, L. (1975). Badania nad ciężarem właściwym kory sosny zwyczajnej (Pinus sylvestris L.) [Research on the specific gravity of the bark of pine (Pinus sylvestris L.)]. Unpublished thesis. Instytut Użytkowania Lasu i Inżynierii Leśnej, Akademia Rolnicza w Poznaniu [in Polish].

\title{
MASA I GESTOŚĆ ŚREDNIOWYMIAROWEGO SUROWCA SOSNOWEGO POZYSKANEGO Z WYBRANYCH DRZEWOSTANÓW LEŚNEGO ZAKŁADU DOŚWIADCZALNEGO W MUROWANEJ GOŚLINIE
}

\begin{abstract}
ABSTRAKT
Celem przeprowadzonej analizy było określenie masy średniowymiarowego surowca sosnowego w stanie świeżym. Badania przeprowadzono na materiale pozyskanym w czterech drzewostanach. Dwa z nich wyrosły na siedliskowym typie lasu boru mieszanego świeżego (w wieku 45 i 56 lat) i dwa - na lesie mieszanym świeżym (47 i 55 lat). Na każdej powierzchni wyznaczono po 30 drzew modelowych, spośród przeznaczonych do wycięcia zgodnie z planowymi zabiegami pielęgnacyjnymi. Przeciętna masa jednego wałka o długości 2,5 m wahała się od 26,3 do 44,0 kg - średnio 33,9 kg. W sumie pozyskano 21,68 $\mathrm{m}^{3}$ surowca o łącznej masie 21 222,4 kg. W przeliczeniu na $1 \mathrm{~m}^{3}$ masę surowca oceniono na $979 \mathrm{~kg}$. Stosunek gęstości rzeczywistej $\left(979 \mathrm{~kg} / \mathrm{m}^{3}\right)$ do tabelarycznej $\left(740 \mathrm{~kg} / \mathrm{m}^{3}\right)$ wyniósł 1,3:1. Rzeczywista masa surowca jest więc o około $30 \%$ wyższa od masy, którą można wyszacować na podstawie tabelarycznej gęstości drewna opracowanej na potrzeby transportu drogowego. Na przekroju podłużnym pnia masa surowca maleje, co jest efektem średnicy pnia zmniejszającej się wraz z wysokością, natomiast rośnie gęstość surowca. Prawdopodobnie wzrost gęstości jest wynikiem zmian w porowatości i wilgotności drewna oraz zmian w masie i właściwościach kory.
\end{abstract}

Słowa kluczowe: gęstość drewna świeżego, transport drewna, ścięte drzewo 